\title{
THE PROFILE OF STUDENTS' EMPLOYMENT IDENTITY STATUS (A STUDY AT COMMUNITY EDUCATION STUDY PROGRAM, FKIP UNIVERSITAS RIAU)
}

\author{
Wilson', Daeng Ayub ${ }^{2}$, Said Suhil ${ }^{3}$, Titi Maemunaty ${ }^{4}$ \\ $\mathbf{1 , 2 , 3 , 4}$ Universitas Riau, Pekanbaru, Indonesia \\ ${ }^{1}$ wilson@lecturer.unri.ac.id, ${ }^{2}$ daeng.ayub@lecturer.unri.ac.id, ${ }^{3}$ said.suhil@lecturer.unri.ac.id, \\ ${ }^{4}$ titi.maemunaty@lecturer.unri.ac.id
}

\begin{abstract}
Teenagers studying at university, known as college students, have the responsibility for themselves; they are demanded to be independent in academic activities as well as to build the identity achievement by searching for information through exploration with sufficient intensity in various fields. After collecting adequate information, they need to make choices (commitment) to the field that suits thei interests and abilities. Based on a discussion conducted in the class, it was revealed that some students felt unsuitable with the study program they took; they did not know the career they would pursue while they were already in the third and fourth semesters. This was survey research with a quantitative approach. This study aimed to obtain an objective description of the Students' Employment Identity Status at the Public Health Education FKIP Universitas Riau. The samples of this study were taken randomly from a population of 104 students. Data on the students' (adolescents) identity status were collected through a questionnaire. Then, the data were analyzed by using descriptive statistical analysis utilizing SPSS. The results of the study found that only $30.77 \%$ of students reached the achievement status while $42.31 \%$ of the students were at the level of moratorium status. In addition, $15.38 \%$ of the students at the level of Forclusure identity status and $11.54 \%$ of them were at the level of diffusion status.
\end{abstract}

Keywords: identity status, employment, late adolescence

\section{PROFILE STATUS IDENTITAS BIDANG PEKERJAAN (STUDI PADA MAHASISWA PROGRAM STUDI PENDIDIKAN MASYARAKAT FKIP UNIVERSITAS RIAU)}

\begin{abstract}
ABSTRAK
Para remaja yang belajar di perguruan tinggi disebut mahasiswa memiliki tanggungjawab atas dirinya, mereka dituntut mandiri dalam kegiatan akademik dan membangun identity achievement dengan melakukan pencarian informasi melalui eksplorasi secara intensitas yang cukup dalam berbagai bidang. Setelah cukup informasi, dilanjutkan dengan menentukan pilihan (Komitmen) terhadap bidang yang sesuai dengan dirinya (minat dan kemampuan). Diskusi dalam kelas ketika pembelajaran, terungkap ada mahasiswa merasa kurang cocok dengan program studi yang di ambil, belum tahu akan berkarir di bidang apa, sementara mereka sudah ada berada di semester 3 dan 4 . Jenis penelitian ini adalah survei dengan pendekatan kuatitatif. Penelitian ini bertujuan untuk mendapatkan gambaran secara objektif tentang Status Identitas Mahasiawa Program Studi Pendidikan Masyarakat FKIP Universitas Riau dalam bidang pekerjaan. Mahasiswa yang berpartisipasi sebagai sampel dalam penelitian diambil secara random dari populasi sebanyak 104 orang. Data tentang status identitas mahasiswa (remaja) dikumpulkan dengan mengunakan instrumen berupa angket. Data setelah terkumpul dianalisis dengan analisis statistik deskriptif dengan menggunakan program SPSS. Hasil penelitian menemukan dari 104 orang mahasiswa yang diteliti hanya $30.77 \%$ orang yang sudah sampai status achievement, ada $42.31 \%$ orang yang berada pada tingkat status moratorium, kemudian ada $15.38 \%$ orang pada tingkat status identitas forclusure, juga ditemukan $11.54 \%$ orang dengan status diffusion
\end{abstract}

Kata Kunci: status identitas, pekerjaan, remaja akhir

\begin{tabular}{|c|c|c|}
\hline Submitted & Accepted & Published \\
\hline 01 Maret 2021 & 19 Juli 2021 & 29 Juli 2021 \\
\hline
\end{tabular}

\begin{tabular}{|l|c|c|}
\hline Citation & $:$ & $\begin{array}{r}\text { Wilson, W., Ayub, D., Suhil, S., \& Maemunaty, T. (2021). The Profile of Students' Employment Identity Status (A Study } \\
\text { at Public Health Education Study Program, FKIP Universitas Riau). Jurnal PAJAR (Pendidikan dan Pengajaran), } \\
5(4), 1094-1101 . \text { DOI }: \text { http://dx.doi.org/10.33578/pjr.v5i4.8460. }\end{array}$ \\
\hline
\end{tabular}

\section{PENDAHULUAN}

Seseorang yang sedang belajar di perguruan tinggi disebut mahasiswa. Mahasiswa pada umumnya berada pada periode perkembangan remaja akhir berusia $18-22$ tahun yang secara fisik sudah menunjukkan dewasa. Masa remaja akhir merupakan masa memasuki masa dewasa, dimana remaja mempersiapkan diri untuk melaksanakan peran sebagai seorang 
dewasa. Pada masa ini juga dikenal masa transisi, yang semula remaja sebagai siswa atau murid berubah menjadi mahasiswa, perubahan juga terjadi pada tugas perkembangan, sudah mulai menyiapkan peran orang dewasa yaitu pekerjaan dan membentuk keluarga. Pada masa inilah oleh ahli perkembangan menyebutnya masa-masa diwarnai aktivits eksplorasi. Mahasiswa memiliki tanggungjawab atas dirinya, oleh karena itu dituntut untuk mandiri yang terkait dengan tugastugas akademik, disamping tuntutan tugas perkembangan, dimana para mahasiswa harus mengambil keputusan tentang masa depannya seperti yang diungkapkan oleh Santrock (2002) dimana sebagai remaja dapat mengambil keputusan secara luas tentang karir, nilai-nilai, keluarga dan hubungan, serta gaya hidup. Pada masa ini yang menjadi tugas perkembangan mahasiswa adalah pembentukan Identitas, yang ditandai dengan ciri-ciri "mencari identitas diri" yaitu masa menjelaskan siapa dirinya dan apa peranannya. Sebagai mana yang diungkapkan oleh Erikson (Miller,1993) pada masa remaja akhir pencarian identitas mencapai klimaks. Artinya pada masa ini remaja sudah terbentuk identity achievement (telah dapat menentukan pilihan) dalam bidang pekerjaan.

Pada era globalisasi, apalagi saat ini memasuki revolusi industry 4.0, yang sarat dengan persaingan ketat, para remaja tidak mudah mendapatkan pekerjaan. Ada kecendrungan di Era Revolusi Industri 4.0, institusi, perusahaan, membutuhkan pekerja dengan keterampilan baru, terampil penggunaan internet, machine, computer. Jadi remaja harus memiliki "identitas dalam bidang pekerjaan" (Vocational Identity Formation). Membangun identitas bidang pekerjaan, remaja harus mulai melakukan pencarian informasi melalui eksplorasi dalam berbagai bidang pekerjaan. Setelah cukup informasi, dilanjutkan dengan menentukan pilihan (Komitmen) terhadap bidang pekerjaan yang sesuai dengan dirinya (minat dan kemampuan).

Papalia, Wendkos dan Feldman (2008) identitas terbentuk ketika remaja berhasil memecahkan tiga masalah utama: pilihan pekerjaan, adopsi nilai yang diyakini dan dijalani, dan perkembangan identitas seksual yang memuaskan. Lebih lanjut Diane E. Papalia dkk, seorang remaja harus memastikan dan mengorganisir kemampuan, kebutuhan, ketertarikan, dan hastrat mereka sehingga dapat diekspresikan dalam konteks sosial. Mencermati pendapat Papalia dkk, seorang remaja harus memiliki kemampuan memilih dan mempersiapkan diri untuk bekerja atau karir. Tugas ini menuntut remaja belajar memilih dan menentukan satu jenis pekerjaan akan ditekuni. Remaja berstatus sebagai mahasiswa melekat pada dirinya memiliki nilai lebih yang disandangkan padanya. Mahasiswa dikalangan masyarakat sudah dipandang seorang dewasa, mereka dianggap memiliki ilmu pengetahuan dan keahlian, sudah terampil. Bila dicermati perilaku keseharian mahasiswa sebahagian adan kecenderungan demikian, namun ada sebahagian yang masih belum memiliki kemandirian. mereka terjebak situasi kebinguan identitas. Hasil penelitian Howard \& Galambos memperlihatkan bahwa peralihan dari masa remaja akhir ke masa dewasa terjadi aspek-aspek kebingungan dalam pekerjaan, pendidikan perguruan tinggi..(2011)

Menurut ahli perkembagangan bahwa tugas perkembangan remaja akhir adalah pembentukan identitas yang ditandai dengan ciri "mencari identitas" Marcia (1993) menyatakan pembentukan identitas memerlukan adanya aktivitas eksplorasi dan aktivitas komitmen. Tingkat keluasan dan intensitas aktivitas eksplorasi dan komitmen yang dilakukan oleh remaja, menentukan status identitasnya. Dalam teori identitas Erikson, dikembangkan oleh Marcia (1993) dan Steinberg (2014) ada 4 kategori status identitas diri yaitu Identity achievement, moratorium, foreclosure dan diffusion. Keempat status identitas ini menjadi ukuran cara remaja mengatasi krisis identitas yang ditandai tingkatan aktivitas eksplorasi dan komitmen. Identity achievement adalah individu yang sudah melakukan eksplorasi (tinggi) dan juga sudah membuat komitmen dengan jelas (tinggi), Moratorium; adalah individu yang melakukan eksplorasi (tinggi) namum komitmen yang dibuat masih belum jelas (rendah), Foreclosure; adalah individu yang tidak melakukan eksplorasi (rendah), tapi telah membuat komitmen yang jelas 
(tinggi), dan Identity Diffusion; adalah individu yang tidak melakukan eksplorasi (rendah) dan juga tidak membuat komitmen (rendah).

Lebih lanjut Marcia (1993) memaparkan sejauhmana aktivitas eksplorasi yang dilakukan remaja dalam mencari informasi tentang masalah pekerjaan tergambar dari keluasan dan intensitas, terlihat dari: 1) Kemampuan untuk mengetahui, yaitu remaja memiliki keinginan untuk mencari tahu tentang jenis, seluk beluk dan kekhasan pekerjaan yang dipilih sesuai dengan minat dan kemampuannya. 2) Aktivitas yang diarahkan untuk mengumpulkan informasi, yaitu kegiatan yang diarahkan untuk mencari informasi tentang pilihan pekerjaan dengan membaca, berdiskusi dan bertanya 3) Pertimbangkan atas pilihan pekerjaan, remaja membuat pertimbangan atas beberapa alternative dari berbagai pilihan yang ada dan hubungan dengan pemilihan pekerjaan seperti untung rugi, disiplin ilmu dan peluang masa depan 4) Keinginan membuat keputusan sejak dini, yaitu memiliki keinginan membuat keputusan untuk memilih pekerjaan lebih awal.

Sementara aktivitas komitmen berkaitan dengan aktivitas/usaha mahasiswa memutuskan untuk memilih suatu jenis pekerjaan yang hendak ditekuni secara mantap setelah mempertimbangkan berbagai pilihan yang ada. Diukur dengan indikator dari konsep Marcia, (1994): 1) Akurasi pengetahuan tentang bidang yang dipilih, keakurasian pengetahuan yang dimiliki remaja pada bidang pekerjaan yang dipilih. 2) Aktivitas yang diarahkan ke bidang yang dipilih, kegiatan yang diarahkan pada penerapan pada bidang pekerjaan yang dipilih. 3) Nada emosi yang muncul saat menentukan pilihan, yaitu perasaan yang muncul/dirasakan disaat menentukan pilihan pekerjaan. 4) Mengidentifikasikan diri pada orang yang dianggap bermakna, yaitu mengidentifikasikan diri remaja terhadap tokoh yang bermakna bagi dirinya yang berkaitan dengan pekerjaan. 5) Memproyeksi yang dipilih pada masa depan, yaitu memproyeksikan/menggambarkan pekerjaan yang dipilih di masa datang akan berhasil, memiliki prospek yang bagus. 6) Daya tahan terhadap godaan, yaitu keputusan untuk bertahan pada pilihan, menghadapi cobaan dan rintangan yang datang kemudian setelah menentukan pilihan

Berdasarkan pendapat ahli, pada periode remaja akhir pencarian identitas individu mencapai puncaknya, sementara fenomena terlihat dari pengamatan terhadap perilaku remaja akhir yang berstatus mahasiswa masih ada yang bimbang, bingung dalam menentukan pilihan khusus dalam bidang penentuan karir atau pekerjaan. Bingung dengan program studi yang sedang diikutinya. Dari diskusi dalam kelas ketika pembelajaran, terungkap merasa kurang cocok dengan program studi yang di ambil, salah pilih, belum tahu akan berkarir di bidang apa, sementara mereka sudah ada berada di semester 3 dan 4 , ada yang mengatakan memilih program studi di awalnya hanya ikutan teman, ada juga saran dari orangtua, ada diantara mereka ini yang minta pindah dan bahkan tidak melanjutkan perkuliahan.

Berdasarkan urain di atas, muncul pertanyaan bagaiman gambaran status identitas mahasiswa dalam bidang pekerjaan, maka tujuan penelitian ini adalah mengetahui status identitas mahasiswa dalam bidang pekerjaan.

\section{KAJIAN TEORETIS}

Erikson menyatakan bahwa pencarian identitas sebenarnya telah dimulai sejak masa bayi, tepatnya saat anak mulai mengenal pengasuhnya dan terus berlanjut hingga masa dewasa (Santrock, 2007). Pada periode remaja akhir pencarian identitas individu mencapai puncaknya. Pada tahap ini remaja akan dihadapkan pada banyak peran dan menemui beragam persoalan tentang siapa mereka, apa yang penting untuk mereka, dan apa yang hendak dituju dalam hidup. Remaja yang mampu menghadapi peran dan identitas yang saling bertentangan akan memiliki suatu kesadaran yang baru dan dapat diterima tentang dirinya, sedangkan remaja yang gagal melalui krisis identitas akan mengalami kebingungan identitas (Santrock, 2014). 
Kebingungan yang terjadi di kalangan remaja, ketika pada saat penentuan kariernya, seperti halnya memilih program di universitas (Patton \& Creed, 2001). Kebingungan identitas akan melahirkan keragu-raguan atau kebimbangan. Fenomen kesulitan atau ketidakmampuan dalam membuat keputusan terkait karier atau pemilihan jurusan di perguruan tinggi. Osipow, Carney, Winer, Yanico, \& Koschier (Celdran, 2011) mengidentifikasi terdapat empat dimensi kebimbangan karier, yaitu terdiri dari: a.lack of structure and confidence, $\mathrm{b}$. perceived extermal barriers, c. approach-approach conflict, dan d. personal conflict. Lack of structure and confidence menggambarkan kurangnya pengenalan diri dan kepercayaan diri individu dalam membuat keputusan karier. Perceived extermal barriers merupakan persepsi negatif individu terhadap faktor di luar dirinya yang dapat menghambat pengambilan keputusan karier. Sementara itu, approach-approach conflict adalah konflik yang dialami oleh individu ketika dihadapkan pada beberapa pilihan yang sama-sama disukai sehingga individu sulit untuk mengambil keputusan. Personal conflict merupakan masalah internal yang dialami individu seperti rasa putus asa dan cemas dalam menghadapi proses pengambilan keputusan karier (Celdran, 2011).

Pandangan Donald Super (Santrock, 2002) konsep diri individu memainkan peranan dalam pemilihan karir. Super percaya bahwa banyak perubahan perkembangan dalam konsep diri tentang pekerjaan yang terjadi di waktu masa remaja dan dewasa muda. Kemudian Super (JohnW Santrock 2002) remaja berusia $18-22$ tahun, mereka mempersempit pemilihan karir dan memulai perilaku yang memungkinkan mereka memasuki tipe karir yang disebutnya sebagai pengkhususan. Ginzberg (Santrock 2002) periode menuju awal usia 20 an disebutnya fase realistic dari pemilihan karir. Pada fase ini katanya, individu mengeksplorasi lebih luas karir yang ada, kemudian memfokuskan diri pada karir tertentu dan akhirnya memilih pekerjaan tertentu.

Mencermati pandangan Santrock, Super dan Ginziberg, perjalanan perkembangan remaja yang berstatus sebagai mahasiswa, adalah terkait dengan tugas perkembangan yang di emban oleh remaja akhir. Menurut ahli perkembagangan bahwa tugas perkembangan remaja akhir adalah pembentukan identitas yang ditandai dengan ciri "mencari identitas". Erick Erikson (Santrok (2007) persoalan paling penting dalam diri remaja adalah perkembangan identitas- pencarian jawaban atas pertanyaan " siapa aku, apa yang akan aku lakukan dalam hidup ini". Artinya pada masa remaja akhir, sudah dapat menentukan pilihan (terbentuk identity achievement ) dalam bidang pekerjaan.

\section{METODE PENELITIAN}

Jenis penelitian ini adalah survei dengan pendekatan kuantitatif. Jenis penelitian ini bertujuan untuk mendapatkan gambaran secara objektif tentang satus Identitas dalam bidang karir melalui Aktivitas Eksplorasi dan Komitmen. Populasi dalam penelitian ini adalah mahasiswa Program Studi Pendidikan Masyarakat FKIP Universitas Riau yang terdaftar pada tahun akademik 2020/2021 sebanyak 220 orang, sedangkan mahasiswa yang berpartisipasi sebagai sampel dalam penelitian ini diambil secara random/acak dari populasi ada sebanyak 104 orang. Data tentang status identitas remaja dalam bidang karir perolehan skor dari aktivitas Eksplorasi dan Komitmen, dikumpulkan dengan mengunakan instrumen berupa angket.

Data Eksplorasi berkaitan dengan aktivitas/usaha yang dilakukan oleh mahasiswa secara aktif mencari, mempelajari untuk mengetahui informasi yang menyangkut jenis, seluk beluk dan kekhasan pekerjaan yang akan ditekuni, untuk melihat tinggi rendahnya aktivitas eksplorasi diukur dengan indikator dari konsep Marcia, (1994): 1) Kemampuan untuk mengetahui, 2) Aktivitas yang diarahkan untuk mengumpulkan informasi, 3) Pertimbangkan atas pilihan pekerjaan, dan 4) Keinginan membuat keputusan sejak dini

Data Komitmen berkaitan dengan aktivitas/usaha mahasiswa memutuskan untuk memilih suatu jenis pekerjaan yang hendak ditekuni secara mantap setelah mempertimbangkan berbagai pilihan yang ada. Diukur dengan indikator dari konsep Marcia, (1994): 1) Akurasi pengetahuan tentang bidang yang dipilih, 2) Aktivitas yang diarahkan ke bidang yang dipilih, 3) 
Nada emosi yang muncul saat menentukan pilihan, 4) Mengidentifikasikan diri pada orang yang dianggap bermakna, 5) Memproyeksi yang dipilih pada masa depan, 6 ) Daya tahan terhadap godaan. Data yang telah terkumpul dianalisis dengan analisis statistik deskriptif dengan menggunakan program SPSS 20

\section{HASIL DAN PEMBAHASAN}

Dari analisis data yang dilakukan menggunakan program SPSS, diperoleh nilai statistik deskriptif berupa nilai maksimum, minimum, sum, mean dan standar deviasi variable Aktivitas Eksplorasi dan variable Aktivitas Komitmen seperti table berikut:

Tabel 1. Descriptive Statistics

\begin{tabular}{lcrrrrrr}
\hline & N & Range & Minimum & Maximum & Sum & Mean & Std. Deviation \\
\hline Eksplorasi & 104 & 44.00 & 70.00 & 114.00 & 100472.00 & 100.6923 & 8.92153 \\
\hline Komitmen & 104 & 43.00 & 78.00 & 121.00 & 10428.00 & 100.2692 & 8.41200 \\
\hline Valid N (listwise) & 104 & & & & & & \\
\hline
\end{tabular}

Data pada tabel 1 dapat digunakan untuk mengetahui tingkatan atau kategori tingkat eksplorasi dan komitmen mahasiswa pendidikan masyarakat FKIP Universitas Riau dengan menggunakan formula dari Sudijono, 2012 sebagai berikut:

$$
\begin{aligned}
& \text { Mean }+(0.25 \mathrm{SD}) \\
& \text { Dari hasil analisis data dengan }
\end{aligned}
$$
menggunakan formula Sudijono (2012), diperoleh hasil tingkat aktivitas eksplorasi mahasiswa dalam bidang karir, ada 76 orang tergolong tinggi eksplorasinya dan 28 orang termasuk rendah eksplorasinya. Sedangkan tingkat aktivitas komitmen mahasiswa dalam bidang karir ada 48 orang tergolong tinggi komitmennya dan 56 orang yang termasuk rendah komitmennya, seperti tertera pada table 2 berikut:

\section{Tabel 2. Deskripsi Tingkatan Aktivitas Eksplorasi dan Komitmen}

\begin{tabular}{lllc}
\hline Aktivitas & Tinggi/\% & Rendah/\% & Total \\
\hline Eksplorasi & $76(73.08 \%)$ & $28(26.92 \%)$ & 104 \\
Komitmen & $48(46.15 \%)$ & $56(53.85 \%)$ & 104 \\
\hline
\end{tabular}

Sumber: Analisis Statistik

Data di atas menunjukkan ada 76 (73.08.\%) mahasiswa yang intensitas dan keluasan tinggi, melakukan aktivitas eksplorasi dalam usaha mencari, mempelajari untuk mengetahui informasi yang menyangkut jenis, seluk beluk dan kekhasan pekerjaan yang akan ditekuni, dan yang sedangkan tingkat aktivitas komitmen yang tinggi berupa usaha memutuskan untuk memilih suatu jenis pekerjaan yang hendak ditekuni secara mantap setelah mempertimbangkan berbagai pilihan yang ada $48(46.15 \%)$. Sementara $56(53.85 \%)$ rendah komitmennya, artinya belum mampu membuat keputusan untuk memilih suatu jenis pekerjaan. Hasil penelitian ini juga menemukan dari 104 orang mahasiswa yang diteliti hanya $32(30.77 \%)$ orang yang sudah sampai status achievement, artinya 32 orang mahasiswa sudah melakukan eksplorasi yang intensitas tinggi dan sudah membuat keputusan komitmen yang tinggi. Ada 44 $(42.31 \%)$ orang yang berada pada tingkat status moratorium, artinya memiliki eksplorasi tinggi tapi belum membuat keputusan komitmen rendah, kemudian ada pula $16(15.38 \%)$ orang pada tingkat status identitas forclusure, artinya yang memiliki 
eksplorasi rendah tapi sudah memutuskan memilih (komitmen tinggi), juga ditemukan 12 (11.54\%) orang yang eksplorasi rendah juga komitmen juga rendah. Datanya dapat dilihat seperti table 3 berikut:

\section{Tabel 3. Status Identitas Mahasiswa PenMas FKIP UNRI}

\begin{tabular}{lcc}
\hline Status Identitas & Jumlah & \% \\
\hline Achievement & 32 & $30.77 \%$ \\
\hline Moratorium & 44 & $42.31 \%$ \\
\hline Foreclusure & 16 & $15.38 \%$ \\
\hline Diffusion & 12 & $11.54 \%$ \\
\hline & 104 & 100 \\
\hline
\end{tabular}

Sumber: Analisis Statistik

Lebih lanjut juga dapat dilihat pada gambar grafik berikut:

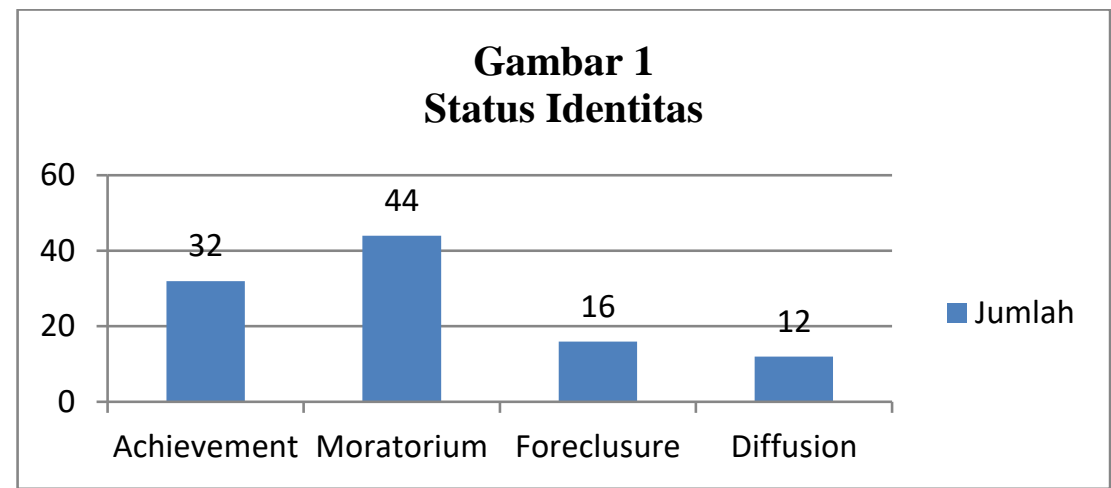

\section{Pembahasan}

Mencermati hasil penelitian ini, tingkat status identitas mahasiswa pada program studi pendidikan masyarakat FKIP Universitas Riau berusia pada tahap perkembangan remaja akhir, baru ada $30.77 \%$ mahasiswa yang sudah tercapai pembentukan identitas vocational (pekerjaan) dengan status achiement. Remaja berstatus mahasiswa berada pada usia remaja akhir seharusnya capaian status identitas mencapai status achievement seperti yang diungkapkan oleh Erikson (Miller,1993) pada masa remaja akhir pencarian identitas mencapai klimaks. Artinya pada masa ini remaja sudah terbentuk identity achievement (telah dapat menentukan pilihan) dalam bidang pekerjaan. Diungkapkan lagi oleh Erikson (Santrock, 2007). menyatakan bahwa pencarian identitas melalui eksplorasi, sebenarnya telah dimulai sejak masa bayi, tepatnya saat anak mulai mengenal pengasuhnya dan terus berlanjut hingga masa dewasa. Dari hasil penelitian ini menunjukkan, hanya baru $30.77 \%$ yang telah melakukan secara aktif melakukan eksplorasi dengan cara mencari, mempelajari untuk mengetahui informasi yang menyangkut jenis, seluk beluk dan kekhasan pekerjaan yang akan ditekuni, yang kemudian berkomitmen memutuskan untuk memilih suatu jenis pekerjaan yang hendak ditekuni secara mantap setelah mempertimbangkan berbagai pilihan yang ada. Ini menandakan $69.23 \%$ lagi mahasiswa belum terbentuk identitas dalam bidang pekerjaan (karir) dengan kata lain belum terbentuk identity achievement.

Berdasarkan temuan penelitian ini, yang belum terbentuk identity achievement, ada pada capaian kategori status moratorium sebesar $42.31 \%$, capaian pada kategori Forclusure sebesar 
$15.38 \%$, dan ada capaian pada ketegori diffusion sebanyak $11.54 \%$. Temuan ini mengindikasikan bahwa proses pembentukan identitas remaja akhir dalam hal ini mahasiswa prodi Pendidikan Masyarakat FKIP Universitas Riau, ada sudah melakukan eksplorasi dengan cara mencari, mempelajari untuk mengetahui informasi yang menyangkut jenis, seluk beluk dan kekhasan pekerjaan yang akan ditekuni, tapi belum membuat komitmen untuk memutuskan memilih salah satu jenis pekerjaan yang hendak ditekuni secara mantap setelah mempertimbangkan berbagai pilihan yang ada. Ada yang belum melakukan eksplorasi tapi sudah membuat komitmen untuk memutuskan memilih. Ada yang sama sekali tidak melakukan eksplorasi dan komitmen. Hasil penelitian yang dilakukan oleh Nuryanto dan Setiowati, (2018) terhadap mahasiswa tingkat pertama FKIP UPY, yang mencapai kategori pencapaian identititas (achievement) sebesar $7.74 \%$, dan umumnya berada pada kategori pencabutan identitas sebesar $46.2 \%$ dan penundaan identitas sebesar $46.03 \%$, tidak ada yang berada pada ketegori penyebaran identitas. Sarwono (2013) mengatakan bahwa pembentukan identitas remaja di Indonesia bukanlah sesuatu yang mudah karena tidak terdapat profil remaja yang seraga dan berlaku secara nasional. Lebih lanjut Sarwono mengatakan hal itu disebabkan remaja Indonesia terdiri dari berbagai suku, adat, status social ekonomi dan tingkat pendidikan. Keberagaman capaian status identitas remaja juga terlihat dari hasil penelitian yang dilakukan oleh Damayanti, (2007) terhadap Remaja Tunanetra Usia 18-22 tahun ini menunjukkan bahwa sebesar $71.4 \%$ remaja tunanetra memiliki status identitas identity achievement, sebesar $19 \%$ memiliki status identitas foreclosure dan masing-masing sebesar $4.8 \%$ remaja tunanetra memiliki status identitas moratorium dan identity diffusion. Penelitian yang dilakukan oleh Koo dan Kim (2016) terhadap mahasiswa keperawatan di Korea, juga memperlihatkan capaian status identitas bidang vocational $31.5 \%$ pada kategori diffusion, $28.3 \%$ pada kategiri moratorium low profile, $14.1 \%$ pada status penyitaan dan 11.3 pada statur achievement. Kroger, Martinussen dan Marcia (2010) melakukan studi cross-section untuk menguji pola perkembangan perubahan status identitas selama masa remaja dan dewasa muda melalui metaanalisis, hasilnya menunjukkan proporsi rata-rata moratorium meningkat terus hingga usia 19 tahun dan menurun setelahnya, sedangkan proporsi ratarata identitas yang dicapai meningkat selama masa remaja akhir dan dewasa muda; status penyitaan dan difusi menurun selama tahun-tahun sekolah menengah, tetapi berfluktuasi sepanjang masa remaja akhir dan dewasa muda.

\section{SIMPULAN DAN REKOMENDASI}

Berdasarkan hasil dan pembahasan penelitian, maka diperoleh simpulan mengenai satus Identitas mahasiswa dalam bidang pekerjaan melalui Aktivitas Eksplorasi dan Komitmen, 32 $(30.77 \%)$ orang yang sudah sampai status achievement, dengan melakukan eksplorasi yang intensitas tinggi dan membuat keputusan komitmen yang tinggi. Ada 44 (42.31\%) orang yang berada pada tingkat status moratorium, memiliki eksplorasi tinggi dengan keputusan komitmen rendah, ada $16(15.38 \%)$ orang pada tingkat status identitas forclusure, dengan memiliki eksplorasi rendah tapi sudah memutuskan memilih (komitmen tinggi), ditemukan $12(11.54 \%)$ orang yang eksplorasi rendah juga komitmen rendah.

Berkaitan dengan temuan penelitian ini, maka perlu diberikan layanan bimbingan karir bagi mahasiswa. Bagi para penelitian yang akan melakukan penelitian tentang pembentukan status identitas remaja agar mempertimbangkan lintas budaya

\section{DAFTAR PUSTAKA}

Baartoszuk, K dan Pittman, J. F. (2010). Profile of Identity Exploration and Commitment Across Domains. Journal of Child and Family Studies Vol 19 page 444 - 450

Celdran, G.(2011). Purpose in life and career indecision as predictors of academic success in college. A dissertation was submitted to the faculty of The 
University of North Carolina. (unpublished).

Damayanti, N. (2007). Studi Deskriptif Mengenai Status Identitas Bidang Vokasional Pada Remaja Tunanerta Usia 18-22 Tahun Yang mengikuti Program Rehabilitasi di Panti Sosial Bina Netra Wyata Guna Bandung. Undergraduate thesis Universitas Kristen Maranatha

Howard, A.L dan Galambos, N.L (2011). Transitions to Adulhood. Encyclopedia of Adolescence 1

Koo, H. Y dan Kim, E. J. (2016). Vocational Identity and Ego Identity Status in Korean Nursing Students. Korean Society of Nursing Science page 68 74

Kroger, J, Martinussen, M dan Marcia, J. E. (2010). Identity Status Change During Adolescence and Young Adulthood: A Meta-Analysis. Journal of Adolescence, Vol 33 page 683 698

Marcia, J. E. (1993). Ego Identity : A Handbook for Psychology Research. Newyork: Springerverlag

Miller, P. H. (1993). Theories of Development Psychology. New York: Freemam and Company

Nuryanto, I. L dan Setiowati, A. (2018). Status Identitas Diri Mahasiswa Tingkat Pertama FKIP Universitas PGRI Yogjakarta tahun 2017/2018. GCOUNS: Jurnal Bimbingan dan Konseling Vol. 3 No1 page 115 - 119

Papalia, D. E, Wendkos, S dan Feldman, R.D. (2008). Human Development (Psikologi Perkembangan). Jakarta: Kencana Prenada. Edisi 9

Partino, H.R. (2006). Kematangan karir siswa SMA. Psikologika, 21

Patton, W., \& Creed, P. A. (2001). Developmental issues in career maturity and career decision status. The Career Development Quarterly, 49 page 336 - 351

Santrock, J. W. (2002). Life-Span Development-Perkembangan Masa Hidup. Jilid II Jakarta: Erlangga

Santrock, J. W. (2007). Psikologi Pendidikan. Edisi kedua. Jakarta: Kencana Prenada Media

Santrock, J. W. (2014). Adolescence New York: McGraw-Hill Companies, $15^{\text {th }}$ Sarwono, S. W. (2013). Psikologi remaja. Jakarta: Rajawali Pers. Edisi Revisi.

Steinberg, L. (2014). Adolescence. New York: McGraw-Hill Higher Education Edition: $12^{\text {th }}$

Sudijono, A (2012). Pengantar Statistik Pendidikan. Edisi 1 Cetakan 24. Jakarta: Raja Grafindo Persada 